DOI: https://doi.org/10.47773/shj.1998.041.5

SCIENCE AND HUMANITIES JOURNAL

Volume 4, 2004, pp. 52-62

\title{
DISTRIBUTION, SPREAD AND MANAGEMENT PRACTICES AGAINST RICE BLACK BUG IN LEYTE II
}

\author{
Mylene Milan Po \\ Leyte State University \\ Visca, Baybay, Leyte \\ and \\ Bimbo T. Mandras \\ Department of Pest Management \\ Leyte State University, Visca, Baybay, Leyte
}

\section{ABSTRACT}

Rice black bug infestation in the island of Leyte was noticed in late 2001 in Libagon, Southern Leyte. Spread of infestation continued irregularly in many municipalities of Leyte in a year. Light trapping, delayed and synchronous rice planting, duck herding, handpicking of rice black bug, fallowing, weeding and application of Metarhizium anisopliae were some of the control strategies done by farmers in reducing rice black bug population. Natural enemies that were observed to be present in the field were Solenopsis sp. (red ant), Micraspis crocet Mulsant (coccinellid beetle), Ophionia nigrofasciata (Schmidt-Goebel) [ground beetle), Metioche vittaticollis (cricket), salticid.(jumping spider), Tetragnatha sp.(four-jawed spider), Lycosa sp. (ground spider), and Oxyopes sp. (lynx spider), Telenomus sp.(Order Hymenoptera, wasp) and M. anisopliae (green muscardine fungus).

KEY WORDS: Rice black bug. Distribution and spread. Control practices. Infestation in Leyte. Scotinophara coarctata.

1I Part of the MS thesis of the senior author 


\section{INTRODUCTION}

The rice black bug, Scotinophara coarctata Fab. of the Family Pentatomidae, is the newest pest of rice in Leyte, although it has been in the Philippines for more than 2 decades now. It was first observed in Palawan probably from Sabah in 1979, and reached Zamboanga in 1992 then slowly spread throughout Mindanao (NCPC, 2000). Hill (1983) as cited by Ito et al. (1993) recorded also this bug in Pakistan, India, Bangladesh, Malaysia, South China and Indonesia. Rice black bug is considered as one of the pests that is difficult to manage in view of its distinct habit. The nymphs and adults aggregate at the base of the rice plants just above the water level during daytime and move to the upper part at night or on an overcast day (lto et al., 1993). This habit makes this insect less vulnerable to the attack of natural enemies and other natural mortality factors, thus, allowing them to increase their population tremendously.

Large numbers of bugs are carried to distant places by strong winds. Adults appear in swarms. The bugs are able to adapt to a wide variety of conditions and are capable of withstanding adverse conditions. They hide in cracks in soil during periods of water stress and during winter. IRRI (2001) also reported that rice black bugs are strongly attracted to light, but not to yellow electric bulbs. Adults are strong fliers. Their flight activity to light traps coincides with lunar cycle. After harvest, adults transfer to swampy areas and feed on wild grasses, while others stay in the soil and remain dormant. Adult rice black bugs can be transported over long distances by ships and other means of transportation. Rice black bugs are also found on varieties that cannot tolerate rice black bug infestation such as $\mathbb{I R} 64, \mathbb{R}$ 66 and Bordagol (Fernandez, 1993).

This paper shows the distribution of rice black bug in Leyte; farmers' practices that contribute and/or limit the spread of this pest in Leyte Province; and the natural enemies of this pest in the field. 


\section{METHODOLOGY}

\section{Survey on the Distribution of Rice Black Bug}

Rice growing areas in Leyte and Southern Leyte were surveyed to gather information on the distribution of rice black bug in Leyte Provinces. Farmers were interviewed to gather information on the approaches/strategies that they use to manage the bug problem. After the survey, a map of the island of Leyte showing the distribution of the rice black bug was drawn and the time the insect was first recorded in the locality was indicated.

\section{Identification of Natural Enemies}

Natural enemies such as parasitoids, predators and pathogens attacking rice black bug at different developmental stages were collected in every field surveyed. Of the natural enemies mentioned above, the parasitoids and pathogens including Metarhizium anisopliae (Metch.) Sorokin were studied further under field condition. For the parasitoids, the percentage parasitism of the rice black bug was determined while for $M$. anisopliae, the effect of the different methods of application was evaluated.

\section{Analysis of Data}

Data gathered were tabulated and analyzed statistically using frequency, percentages, means and analysis of variance whenever applicable.

\section{RESULTS AND DISCUSSION}

\section{Rice Black Bug Occurrence and Distribution}

Figure 1 shows the occurrence and distribution of rice black bug in Leyte and Southern Leyte. From the interview with the municipal agricultural officer and farmers, the first record of rice black bug 
infestation in the island of Leyte was noted in Barangay Bugasong, Libagon, Southern Leyte in August 2001; infestation then progressed northward. It was recorded in the neighboring town of Sogod, Southern Leyte in October 2001, then in November of the same year, rice black bug infestation was observed in Bontoc, Southern Leyte, and Matalom, Albuera and Ormoc City in Leyte. In year 2002, rice black bug infestation in the other towns of the western part of Leyte came out almost at the same time. For instance, in the towns of Bato and Baybay, infestation was recorded in September. The occurrence of rice black bugs in the towns of Hilongos (October 2002) and Inopacan (December 2002) was believed to be due to the movement of the pest from nearby rice black bug infested towns. On the eastern part of Leyte particularly in the towns of Mahaplag, Abuyog, McArthur, Javier and Dulag, the rice black bugs moved one town after the other in that order at one month intervals.

From the above pattern of movement of rice black bugs, it can be inferred that the introduction of rice black bugs to Leyte and their subsequent dispersal in the island might be attributed to the behavior and flight activity of the insect. Estoy et al. (2000) mentioned that rice black bugs were attracted to high intensity lights such as those in ferries/boats. They further stated that this insect was more active during moonlight nights particularly 3 days before and 3 days after the full moon, allowing for massive dispersal of the insect during this period. Most likely the rice black bugs that were first recorded in Libagon, Southern Leyte might have been introduced into this town from Mindanao. Estoy et al. (2000) reported that rice black bugs infested rice plantings in Mindanao, spreading over the Autonomous Region of Muslim Mindanao (ARMM) areas and moving north. Incidentally, a ferry and other sea crafts plyed regularly between Mindanao and Leyte hence, it was strongly believed that rice black bugs that infested rice plantings in Leyte were introduced through the vessels plying regularly in this route. Moreover, the observation of rice black bug infestation in Albuera and Ormoc City in Leyte which is more than a hundred kilometers away from the town of Libagon, Southern Leyte where it was first sited, further suggests that the movement of rice black bug to Albuera and Ormoc City was facilitated by means other than their flight activity alone. This observation might also be attributed to the vessels plying from Mindanao to Ormoc City. 


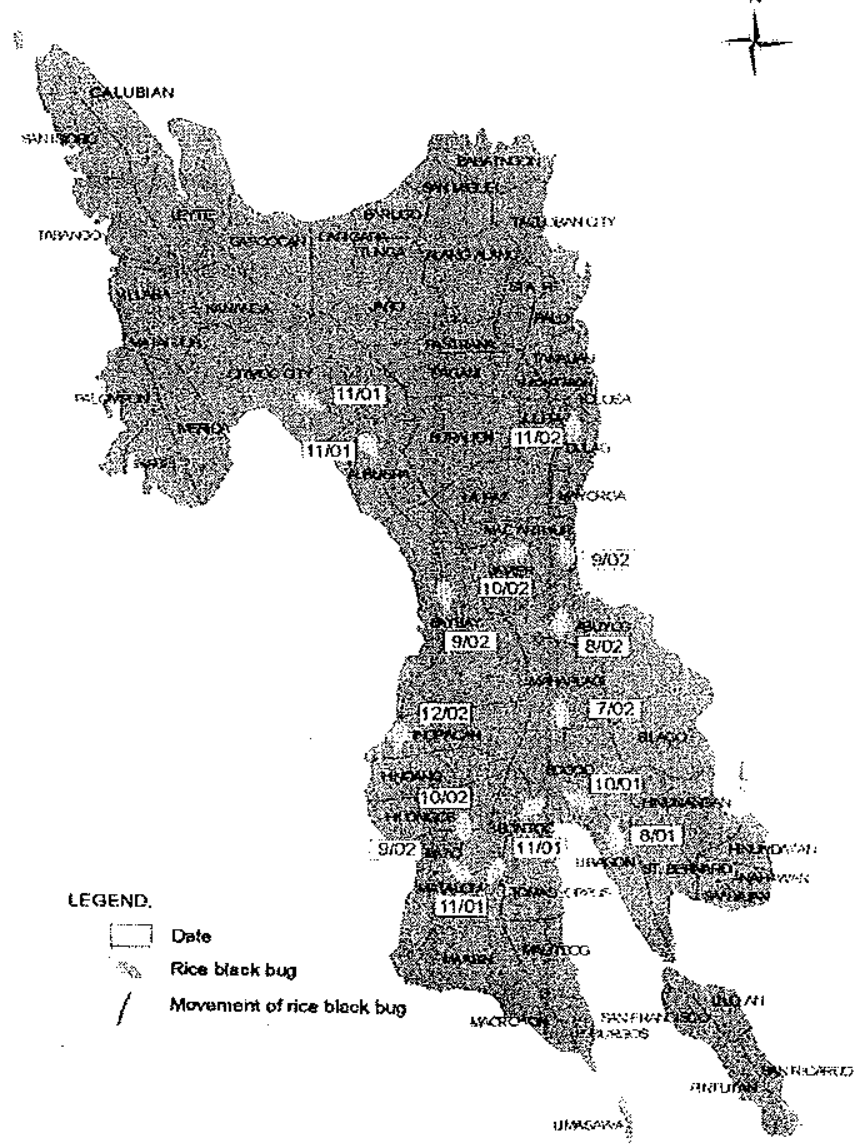

Figure 1. Map of the island of Leyte and Southern Leyte showing the movement of rice black bug from August 2001December 2002. 
The dispersal of rice black bug after its introduction in Leyte was quite slow. For instance, the spread of the rice black bug from Southern Leyte to other parts of Eastern Leyte took a month from one town to the other. This suggests that dispersal of rice black bug in these areas was due to the insects' flight activity. It could also be noted that in Leyte most barangays were already well lighted. Most likely these lighting facilities contributed to the dispersal of the rice black bug. In Western Leyte, a similar trend of rice black bug dispersal, was also noted except in the town of Hindang where no rice black bug outbreak was observed. No infestation of rice plantings in that town could be attributed to the absence of rice plants because of lack of irrigation.

\section{Status of Rice Black Bug Problem in Leyte}

Rice black bugs threatened the rice industry in Leyte shortly after its entry into the island. Results of the survey revealed that reduction in rice yield in the rice black bug-infested areas ranged from $0-100$ percent. The mean yield of rice from the 12 'infested areas before rice black bug infestation was 115.98 sacks/cropping per hectare but it was significantly reduced to 61.62 sacks/cropping per hectare after rice black bug infestation (t-test value of 5.649 at $1 \%$ level of significance). In Albuera, Leyte, one of the towns severely hit by this pest, farmers reported up to $87 \%$ reduction in rice yield. Almost the same amount of yield loss was recorded by farmers from nearby barangays in Baybay and Ormoc City, Leyte.

\section{Management Approaches Against Rice Black Bug in Leyte}

The sudden outbreak of the rice black bug problem prompted farmers and officials to devise means to control the insect. They did light trapping of the pest using a 500-watt white light bulb for 3 days before and 3 days after the full moon. Mendoza and Batomalaque (1999) 
mentioned that white light attracted the highest number of rice black bugs compared with other light trap colors hence, it was recommended for use during light trapping activities.

In addition, flooding the field to reduce egg hatchability was also practiced by other farmers. Parducho et al. (1988) observed that eggs of rice black bugs submerged in water for 6,12 and 18 hours, had 33, 29 and $3 \%$ hatchability, respectively, but had $96 \%$ hatchability when the eggs were not submerged in water.

Moreover, delayed and synchronous rice planting was also practiced by farmers in other areas and in Albuera, Leyte particularly in Barangay Balugo. The purpose of this strategy was to deprive the rice black bugs of their host plant. In addition, duck herding, handpicking of rice black bug, and fallowing and weeding the area also minimized rice black bug population. $M$. anisopliae mass produced by the Department of Agriculture was also distributed to the farmers to get rid of this pest problem.

In other areas, farmers eager to control the rice black bug resorted to over application of pesticides and/or use other chemicals not intended for pest control purposes. In many instances, these chemicals not only killed the pests but also affected their crops. Pesticide application must be the last resort since not only rice black bugs were affected but also the natural enemies. Perez et al. (1989) reported that insecticides that destroy these natural enemies could increase the frequency of rice black bug outbreaks.

\section{Other Mortality Factors}

Natural enemies. Results of the survey conducted in the different rice black bug-infested fields (Table 1) revealed that predatory and parasitic arthropods abound in many rice fields, thus providing control of the rice black bug. However, rice black bug population was higher in some areas, probably due to the low population of the natural enemies especially in areas where pesticide application was rampant. 
Table 1. Predatory and parasitic arthropods collected in the field survey conducted from November to April 2003.

\begin{tabular}{|c|c|c|c|c|c|c|c|c|c|c|c|c|}
\hline \multirow{2}{*}{$\begin{array}{l}\text { Sampled } \\
\text { Arthropods }\end{array}$} & \multicolumn{12}{|c|}{ Place Collected } \\
\hline & $\begin{array}{c}\text { Ormoc } \\
\text { City }\end{array}$ & $\begin{array}{l}\text { Libayon } \\
\text { So. Leyre }\end{array}$ & $\begin{array}{l}\text { Mahaplag. } \\
\text { Leyte }\end{array}$ & \begin{tabular}{|c|} 
sogood \\
so. Leyle
\end{tabular} & \begin{tabular}{|l|} 
Bontoc \\
So. Letse
\end{tabular} & $\begin{array}{l}\text { Bata, } \\
\text { Leyte }\end{array}$ & $\begin{array}{l}\text { Ahiyong, } \\
\text { Leyte }\end{array}$ & $\begin{array}{l}\text { Javier, } \\
\text { Lere }\end{array}$ & McArthut, & Abuera, & Inopacan, & Baybay \\
\hline \multicolumn{13}{|l|}{ Predators } \\
\hline Micraspis crocea & +4 & tht & & \pm & $+4+$ & + & ++4 & & $+4+$ & & $\$+4$ & t+t \\
\hline Solenopsis sp. & + & $+t+$ & tt+ & t+t & t+t+ & + & $+t$ & & & $t_{t+4}$ & +4 & tot \\
\hline $\begin{array}{l}\text { Metioche } \\
\text { viltaticollis }\end{array}$ & + & +4 & +4 & + & tt & & & & & & + & $4+$ \\
\hline $\begin{array}{l}\text { Ophionia } \\
\text { nigrofasciala }\end{array}$ & & + & & & & + & & & & & & \\
\hline Lycosa sp. & $t+t$ & & +4 & + & $+t$ & & & + & & & + & \\
\hline Oxyopes sp. & \pm & & 4 & & & & & + & & + & $t+t^{+}$ & $4+4$ \\
\hline Tetragnatha sp. & +++ & & + & & $t+$ & + & & + & 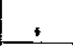 & + & + & \\
\hline Salticid & & + & & + & + & & & & & & & \\
\hline \multicolumn{13}{|l|}{ Parasitoid } \\
\hline Telenomus sp. & & • & + & & & & & & & & & \\
\hline
\end{tabular}

Legend:

1-5 arthropod population $=+$

6-10 arthropod population $=++$

More than 10 arthropod population $=++$

Solenopsis sp., and Micraspis crocea Mulsant reported by Estoy et al. (2000) and Perez et al. (1989) as predators of eggs, nymphs, and adults and on eggs of rice black bugs, respectively, were present in some areas. The cricket (Metioche vittaticollis (Stal.) was also reported to be predatory on the rice black bug particularly the eggs (Estoy et al. 2000) Ground beetles, Ophionia nigrofasciata Schmidt-Goebel were also observed in the field. Aside from insect predators, various species of spiders were collected from the different fields sampled. These included salticid, Tetragnatha sp., and Oxyopes sp. Perez et al. (1989) however, stated that the impact of this natural enemy community on rice black bug population was not determined, but with their behavior and microhabitat preferences, it is likely that they are capable of regulating the rice black 
bug population. The egg parasitoid Telenomus sp. and an entomopathogen, $M$. anisopliae, were also observed to be naturally present in the field.

\section{CONCLUSION AND RECOMMENDATION}

\section{Conclusion}

- Rice black bug infestation in the island of Leyte started in year 2001 and was observed in Libagon, Southern Leyte. Spread of infestation continued to other neighboring municipalities during a year period.

- Farmers and government officials sought ways to prevent further distribution of this pest such that different pest control strategies such as light trapping, flooding the field, delayed and synchronous rice planting, duck herding, handpicking of rice black bug, fallowing, weeding the area, application of $M$. anisopliae and pesticides were implemented.

- Various predators, parasitoids and entomopathogen of rice black bugs were found in the field.

\section{Recommendation}

Survey on the distribution and extent of rice black bug infestation in the Province of Leyte should be continued to determine the population dynamics of rice black bug which would be useful to forecast infestation.

\section{LITERATURE CITED}

ESTOY, A. B., E. H. BATAY-AN, H. X. TROUNG, and L. B. FLOR. 2000. Management of the rice black bug. Rice Tech. Bull. No. 31: $1-11$. 
FERNANDEZ, R. A. 1993. Rice black bug ravaging crops in Western Mindanao. PhilRice Newsletter 6 (4): 5.

ITO, K., H. SUGIYAMA, N. M. SALLEH, and C. P. MIN. 1993. Effects of lunar phase on light trap catches of the Malayan black bug, Scotinophara coarctata (Heteroptera: Pentatomidae). Bull. Entom. Res. 83: 59-66.

INTERNATIONAL RICE RESEARCH INSTTITUTE (IRRI). 2001. Rice IPM. The University of Queensland. An Interactive Information and Identification System for IPM of Rice.

MENDOZA, O. S. and E. G. BATOMALAQUE. 1999. Response of Malayan black bug (Scotinophara coarctata F.) to light colors. USM CA Res. J. 10 (1): 44-46.

NATIONAL CROP PROTECTION CENTER (NCPC). 2000. Management of rice black bug. NCPC, UPLB-CA. University of Southern Mindanao, Philippines. 7 pp.

PARDUCHO, M. A., G. S. ARIDA AND B. M. SHEPARD. 1988. Effect of flooding on Malayan black bug egg hatching and parasitoid emergence. IRRN 13 (6): 39.

PEREZ, V., B. M. SHEPARD, and G. S. ARIDA. 1989. Indigenous natural enemies of the Malayan black bug, Scotinophara coarctata (Fab.) in Palawan. Phil. Ent. 7 (5): 485-490. 


\section{ABOUT THE AUTHOR}

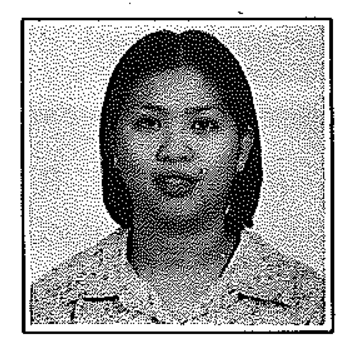

The author obtained her Bachelor of Science in Agriculture major in Plant Protection (Entomology) from the then Visayas State College of Agriculture (ViSCA), now the Leyte State University (LSU), Cum Laude in 1999. After graduation, she pursued her graduate studies at LSU leading to the degree of Master of Science major in Entomology as Graduate Teaching Assistant (GRA) teaching General Biology laboratory classes until she was hired as parttime instructor at the Department of Pest Management (DPM) teaching Plant Protection 21 laboratory classes.

The co-author is a professor at the Department of Pest Management and is the major adviser of the senior author. 